DOI: $10.17805 /$ trudy.2019.1.1

\title{
ИСТОРИЯ ПСИХОЛОГИИ КАК НАПРАВЛЕНИЕ ПСИХОЛОГИЧЕСКОЙ НАУКИ И ПРОСТРАНСТВО ТВОРЧЕСКОЙ САМОРЕАЛИЗАЦИИ ИНДИВИДУАЛЬНОСТИ УЧЕНОГО
}

\author{
Ю. Н.Олейник \\ Московский гуманитарный университет,

$$
\begin{gathered}
\text { В. А. Кольцова } \\
\text { Институт психологии РАН }
\end{gathered}
$$

Аннотация: В статье обозначено проблемное поле истории психологии, дана характеристика одной из последних конференций по истории психологии, посвященной перспективному направлению истории психологии - кросс-культурным и междисциплинарным исследованиям в этой области, впервые приводится полный текст интервью известного отечественного историка психологии В. А. Кольцовой, которое она дала в 2007 г.

Ключевые слова: история психологии; российская психология; советская психология; В. А. Кольщова; биография; историко-психологические исследования; личность ученого; творческая индивидуальность; междисциплинарные исследования в психологии

\section{HISTORY OF PSYCHOLOGY AS A DIRECTION OF PSYCHOLOGICAL SCIENCE AND THE SPACE OF CREATIVE SELF-ACTUALIZATION OF THE INDIVIDUALITY OF THE SCIENTIST}

\author{
Yu. N. Oleinik \\ Moscow University for the Humanities,$$
\text { RAS Institute of Psychology }
$$

Abstract: The article identifies the problem field of the history of psychology, describes one of the latest conferences on the history of psychology, devoted to the promising direction of the history of psychology - cross-cultural and interdisciplinary research in this area. For the first time, the authors present the full text of the interview with a well-known Russian historian of psychology V. A. Koltsova, which she gave in 2007.

Keywords: history of psychology; Russian psychology; Soviet psychology; V. A. Koltsova; biography; historical and psychological research; personality of the scientist; creative individuality; interdisciplinary research in the history of psychology

\section{Необходимое предисловие}

История психологии является одной из ключевых, или как принято говорить, базовых, отраслей психологической науки. Она тесно и органично связана с разработкой теоретических и методологических проблем пси- 
Научные труды Московского гуманитарного университета

2019 № 1

хологии и, одновременно, основывается на исследованиях в конкретных областях (отраслях) психологии. Имея в качестве предмета своего исследования генезис психологических идей в их исторической ретроспективе, она, вместе с тем, выступает как важный инструмент оценки и современного состояния психологического знания, а так же как основа прогнозных оценок его дальнейшего развития. Проблемное поле истории психологии достаточно широкое и включает историю развития психологии в различные хронологические периоды, в разных научных центрах и регионах, изучение творческого наследия мыслителей и ученых, историю разработки отдельных психологических проблем и развития отдельных направлений психологической науки. А еще остаются теоретические и методологические проблемы собственно историко-психологических исследований, вопросы их источниковедческой базы и историографического обобщения и анализа. Одним словом, история психологии дает возможность творческой самореализации как психологам, специализирующимся в данной области психологической науки (сообщество профессиональных историков психологии), так и специалистам, работающим в других направлениях, но готовым к историко-научным обобщениям и характеризующимся пониманием преемственных линий в динамике психологических знаний.

Современная российская история психологии развивается достаточно интенсивно и последовательно, о чем свидетельствуют и количество защищаемых диссертаций, и количество научных публикаций, и количество проводимых научных мероприятий. Начинают формироваться новые и перспективные линии дальнейших историко-психологических исследований. В частности, появились международные проекты историко-психологических исследований с участием российских историков психологии, а реализация междисциплинарных и кросс-культурных разработок по истории психологии многими специалистами рассматривается как необходимое и важное направление будущих историко-психологических исследований.

С целью оценки уже полученных результатов в этой области, определения первостепенных задач и выявления возможных конструктивных направлений дальнейших исследований в рамках этой линии историко-психологических разработок 24-25 ноября 2018 г. в Москве была проведена научная конференция «Кросс-культурные и междисциплинарные исследования в истории психологии: результаты и достижения». Организаторами конференции выступили Институт психологии РАН и Московский гуманитарный университет. Конференция была проведена в рамках международного научного гранта, финансируемого Российским фондом фундаментальных исследований (грант № 18-513-18017) и Национальным научным фондом Болгарии (грант № ДНТС/ Русия 02/19, 18.06. 2018 г.). Часть материа- 
лов, представленных на конференции в формате докладов, публикуется в данном номере журнала.

Предваряют статьи, подготовленные участниками конференции, материалы интервью известного ученого и организатора науки, авторитетнейшего специалиста в области теории и истории психологии, Лауреата Премии РАН им. С.Л. Рубинштейна, заместителя главного редактора и члена редакционной коллегии «Психологического журнала», члена экспертного совета ВАК при Министерстве образования РФ по педагогике и психологии, заведующей лабораторией истории психологии и исторической психологии РАН, профессора кафедры общей психологии и истории психологии Московского гуманитарного университета доктора психологических наук, профессора Веры Александровны Кольцовой (1947-2018). Она была одним из активных участников российско-болгарского научного проекта «Развитие психологической науки в период Второй мировой войны в Болгарии и Советском Союзе: характеристика, особенности, последствия» о котором шла речь выше и одним из инициаторов проведения этой конференции. К сожалению, скоропостижный уход из жизни этого известного российского историка психологии (8 ноября 2018 г.) не дал ей возможности, как она собиралась, сделать доклад на конференции. Вместе с тем, очень хотелось, чтобы мысли и размышления Веры Александровны, которая более 35 лет посвятила изучению проблем отечественной психологии, были представлены в материалах конференции, которую организаторы посвятили ее светлой памяти.

Поэтому, считаем возможным и необходимым включить в материалы конференции ранее не издававшееся интервью В. А. Кольцовой, которое может рассматриваться как своего рода научное завещание историкам психологии.

История появления этого интервью достаточно прозаична. В 2007 г. В. А. Кольцова отмечала 60-летний юбилей. В этой связи возникла идея взять у нее интервью и побеседовать о ее жизненном пути, представлениях об истории психологии, творческих планах и замыслах, об отношении к истории отечественной психологии, о перспективы этой отрасли психологического знания. Вера Александровна как скромный человек долго отказывалась - она с большим желанием готова была говорить об ученых, чье творчество изучала, чем о себе. Однако, в конечном результате она согласилась дать интервью, которое мы и представляем на суд читателя.

Собеседником Веры Александровны в процессе интервью являлся ее ученик и коллега Ю. Н. Олейник, им же даны необходимые комментарии к интервью. Аудиозапись интервью проходила в Институте психологии РАН, в кабинете Веры Александровны на 4 этаже, в сентябре 2007 г. Аудиозапись в настоящее время хранится в личном архиве Ю. Н. Олейника. 
Интервью готовилось к публикации в электронном научном журнале «Психея + Клио» (в настоящее время не издается) и поэтому ему предшествовала небольшая справка о научной биографии В. А. Кольцовой, которую мы оставляем в неизменном виде, так как она и была подготовлена в 2007 г.

\section{ЮБИЛЕЙ КАК ЭТАП ТВОРЧЕСКОЙ ЖИЗНИ}

Ю. Н. Олейник (Москва)

Есть ученые, чей вклад в разработку какой-то проблематики оказывается особенно значим и это можно рассматривать как серьезную научную удачу исследователя. А если такой вклад внесен не в одну, а несколько исследовательских областей? Тогда вполне уместно говорить об основательных научных заслугах ученого, о том, что это не случайность, а серьезный творческий успех. Такие слова можно с полным основанием сказать о докторе психологических наук, профессоре В. А. Кольцовой, заместителе директора Института психологии РАН, заведующей лабораторией истории психологии и исторической психологии ИП РАН, профессоре кафедры общей психологии и истории психологии Московского гуманитарного университета, руководителе секции «История психологии» Российского психологического общества.

В. А. Кольцова пришла в психологию в 1973 г., поступив после окончания с красным дипломом исторического факультета Челябинского государственного педагогического института (1970) в аспирантуру только что созданного Института психологии РАН. С тех пор ее судьба неразрывно связана именно с этим академическим учреждением.

В. А. Кольцова была в числе первых учеников член-корреспондента РАН Б. Ф. Ломова, которым он поручил разрабатывать новое и перспективное направление в психологии того периода - психологию общения. Ее кандидатская диссертация «Общение и формирование понятий» (1977) была посвящена исследованию влияния непосредственного общения на усвоение понятий и изучению ряда факторов, которые определяют характер и степень этого воздействия. В ходе проведенного ею экспериментального исследования (само включение общения в психологический эксперимент уже означало выход на качественно новый уровень его изучения), было убедительно показано, что включение общения в процесс усвоения понятий существенно определяет динамику и результаты данного процесса, а важным фактором повышения продуктивности мыслительной деятельности в условиях общения является информационное взаимодействие его участников. Затем были совместные с американскими психологами исследования личностных детерминант общения в условиях совместной позна- 
вательной деятельности (1982-1983), описание онтологической картины предмета психологического анализа общения и выявление его взаимосвязанных характеристик, содержательный анализ самого процесса общения, выявление основных тенденций в разработке проблем взаимосвязи общения и познавательных процессов. Многочисленные публикации на эти и другие темы, интересные экспериментальные работы В. А. Кольцовой и сегодня привлекают исследователей продолжающих общепсихологические и социально-психологические исследования общения.

Однако уже в ходе исследования проблем общения начал формироваться интерес В. А. Кольцовой и к еще одной проблемной области психологии - к истории возникновения, формирования и развития психологических идей. Ретроспективный анализ социально-психологических взглядов Г. В. Плеханова, проблемы общения в трудах В. М. Бехтерева - ее первых историко-психологических работах, показали, что В.А. Кольцова не только хороший экспериментатор, что она продемонстрировала занимаясь исследованиями общения, но и тонкий, очень глубокий и объективный историк психологии. Именно поэтому, когда в Институте психологии РАН была созданы сначала группа, а потом и лаборатория по истории психологии, именно ей было доверено руководство этими подразделениями.

Сегодня В. А. Кольцова - признанный авторитет в научном сообществе. Ее историко-психологические работы посвящены широкому кругу вопросов: теоретико-методологическим проблемам историко-психологических исследований, проблемам источниковедения и историографии истории отечественной психологии; изучению творческого наследия отечественных ученых и психологов (А. Ф. Лазурский, Б. Ф. Ломов, Н. А. Рубакин, С. Л. Рубинштейн, Л. И. Мечников и др.), историков психологии (Б. Г. Ананьев, Е. А. Будилова, Б. М. Теплов, М. Г. Ярошевский и др.); изучению развития психологии в отдельные исторические периоды (XVII век, II Мировая война и Великая Отечественная война, XX столетие и др.); разработке отдельных проблем психологического познания (научные дискуссии как единица анализа в историко-психологическом исследовании, использование количественных методов в изучении истории психологии, развитие отечественной психогигиены, концептуализация и операционализация процедуры реконструкции в историко-психологических исследованиях и др.). Ее докторская диссертация «Теоретико-методологические основы истории психологии», блестяще защищенная в 2004 г., посвященная обоснованию целостного подхода к изучению истории психологии с позиций системности и комплексности, онтологическому анализу предмета истории психологии и концептуализации ее объекта, стала заметным явлением в научном сообществе.

В. А. Кольцова является активным пропагандистом достижений отече- 
Научные труды Московского гуманитарного университета

2019 № 1

ственной психологии, она выступила одним из инициаторов издания и руководителем серии «Памятники психологической мысли». Она постоянно участвует в подготовке молодых психологов, осуществляя уже более 10 лет преподавательскую деятельность в Московском гуманитарном университете и других вузах страны, под ее руководством подготовлено и успешно защитилось 15 аспирантов.

От имени коллег, учеников и друзей пожелаем В. А. Кольцовой новых творческих достижений на ниве психологического познания самой сложной, но и самой благодатной реальности - Психеи.

\section{ИНТЕРВЬЮ В. А. КОЛЬЦОВОЙ, 2007 ح.}

Итак, мы беседуем с Верой Александровной Кольцовой, заместителем директора Института психологии РАН, доктором психологических наук, заведующей лабораторией психологии и исторической психологии Института психологии РАН, одним из ведущих российских специалистов в области истории психологии ${ }^{1}$.

- Уважаемая Вера Александровна, расскажите, пожалуйста, почему и как в вашей творческой биографии появилось такое понятие как «история психологии». Я знаю, что Вы историк по базовому образованию. Тем самым интерес к истории психологии, вроде бы, был предопределен с самого начала. Однако, он появился не сразу? Какие причины привели к этому?

- Я думаю, что отчасти в таком развернутом вопросе вы дали ответ на него. А он заключается в следующем: базовое историческое образование, которое я получила, конечно, определяло интерес к рассмотрению историко-генетических проблем. И поэтому всегда интересовала и история страны, и история культуры, и история научной мысли. Но другое дело, что интерес был латентный, потому что сферой моих научных интересов, которые первоначально сформировались в области психологии, выступали проблемы общения. Хотя даже когда еще проблема общения [меня] занимала, волновала, была главной в области профессиональных интересов, и, более того, в этой области выстраивались какие-то перспективные планы, возникали какие-то надежды на [профессиональное] будущее, и даже тогда исторический аспект [в моем творчестве] все равно присутствовал. Присутствовали

\footnotetext{
${ }^{1}$ При подготовке к публикации текста интервью мы постарались вносить минимальные, лишь стилистические и орфографические правки в сам текст. Хотелось, чтобы читатель услышал «живую речь» Веры Александровны. Все дополнительные включения в текст (для облегчения его логического восприятия) и не принадлежащие Вере Александровне мы заключили в квадратные скобки.
} 
попытки рассмотреть историогенез проблемы, выделить основные тенденции разработки проблемы в отечественной психологии, описать ведущую школу в этой проблеме - школу Ломова и специфику исследований общения в этой школе. И хотя это было, несколько может быть, наивно, это был взгляд, так сказать, на уровне даже больше здравого смысла, нежели с учетом какого-то специального методологического инструментария, характерного для историко-психологического исследования, но это была уже первая попытка реализовать исторический интерес в той области.

Ну а что касается уже собственно перехода, очень ответственного, очень сложного, перехода связанного с изменением вообще сферы научной деятельности, то это фактически означало - начать с «чистого листа», начать снова с исходной точки. И это в то время, когда была уже защищена кандидатская диссертация, когда были уже публикации по проблеме общения, уже, так сказать, «засветилась» в этой проблемной области и определила исследовательские перспективы. Так вот, надо было вдруг «броситься» в новую проблематику, начать фактически с нуля разработку новой проблемы. Я думаю, что тут помимо базового интереса к истории вообще, хотя это фактор важный, сыграл большую роль личностный фактор - прежде всего влияние Б. Ф. Ломова, моего наставника, учителя, человека безгранично авторитетного для меня и уважаемого, любимого мной, который, вероятно что-то почувствовал, что-то увидел во мне. Он был мудрым человеком и взгляд, наверное, у него был очень правильный, представления о людях очень адекватные и он решил, что более полезными мои усилия будут именно в этой области. В любом случае, так он решил и потихоньку, методом постановки передо мной каких-то конкретных задач, буквально втягивал меня в их решение. Например, попросил подготовить большую обзорную статью о тенденциях развития разработки проблемы общения в отечественной психологии, затем попросил описать те этапы, которые могут быть выделены в разработке проблем общения в стенах нашего института, описать специфику той школы общения, которая была им создана. Такие статьи были подготовлены, они, вероятно, произвели какое-то позитивное впечатление, потому что на следующем этапе он сделал [уже] совсем, кажется, неординарный шаг - предложил написать статью о Плеханове «Социально психологические идеи в творчестве Плеханова» ${ }^{1}$ и, более того, принес литературу и всячески стимулировал мою работу.

Было, конечно, немного страшно и ответственно [браться за такую работу], но когда историк по образованию, взял в руки первоисточники и начал работать, тут все сомнения ушли на задний план. Да, тут сказалось базовое

${ }^{1}$ (Кольцова, 1981). 
Научные труды Московского гуманитарного университета 2019 № 1

образование и поэтому вдруг возник интерес, какой-то азарт, «заблестели» глаза, захотелось поглубже что-то узнать и, собственно, вот это и был тот самый первый, сложный, может быть критический шаг, который потом уже вылился в какую-то новую научную ориентацию. Ну, естественно, переход этот был постепенный, какое-то время я продолжала заниматься и проблемами общения. Однако, в целом, больший удельный вес в научной проблематике стал уже уделяться истории психологии, потому что очень важной вехой, [кроме сказанного] может быть, явилось и то, что было решено провести конференцию, посвященную столетию образования первой экспериментальной психологической лаборатории в нашей стране ${ }^{1}$. В связи с подготовкой к конференции, мне пришлось углубиться и в материалы касающиеся личности создателя лаборатории Владимира Михайловича Бехтерева, и его творческого пути, разыскивать архивы, первоисточники, которые позволят достоверно восстановить этот важный момент в истории развития нашей отечественной науки ${ }^{2}$. И это показалось тоже очень увлекательным, очень интересным. Все это может быть и стало теми причинами, которые привели к тому, что на личностном уровне было отрефлексировано, что, наверное, это действительно та область, которая вызовет наибольший интерес и будет наиболее адекватна для моих собственных возможностей.

- Сегодня, вы очень авторитетный, известный историк психологии...

- Ой, спасибо.

- Это оценка не только моя, это мнение ваших коллег, это находит отражение во многих фундаментальных публикациях, которые у вас есть, в отношении к вам в психологическом сообществе. В этой связи уточните, что необходимо историку психологии? Вы говорили о том, что вы очень долго шли к тому, чтобы принять эту проблематику как личностную. Вот сегодня, с высоты своего достаточно длительного, долгого пути в истории психологии, наверное, вы можете сказать, какие качества необходимы историку психологии? Есть какая-то специфика в этих качествах?

- Так, ну что мне кажется, первое и самое важной - это накопление большого массива фактологического материала для успешной работы историка, это определенное профессионально-значимое качество: умение работать с конкретным материалом и умение его собирать. Когда-то мне К.К. Платонов сказал: «Чтобы успешно работать в истории психологии, надо предварительно 10 лет работать с материалом». То есть создание какой-то фактологической основы, как своеобразной «подушки безопасно-

\footnotetext{
${ }^{1}$ O работе конференции см.: Кольцова, Олейник, 1986.

${ }^{2}$ Напомним читателю, что по итогам этой конференции были изданы два сборника научных трудов: История и некоторые вопросы ... , 1989; История становления ... , 1990.
} 
сти», которая убережет в критических ситуациях, как фундамента, на котором только и может строиться здание историко-психологического знания. Без такой накопленной фактологии, конечно никакие обобщения в истории не возможны, это все-таки теоретическая дисциплина, она представляет собой по сути некую теоретическую систематизацию, обобщение так сказать, большой совокупности материала, накопленного на больших периодах в истории человечества, в истории культуры, в истории страны или научного сообщества, и поэтому - умение собирать материал, интерес и вкус к накоплению фактологии. Именно эта ориентация на углубление и широкую фактуальность, есть не у каждого. Прежде чем выйдет какая-то работа по истории [психологии], необходима эта рутинная работа по сбору фактов, нужна большая работа чернорабочего, такого, который будет «раскапывать эту породу», находить там какие-то крупинки, эти крупинки извлекать, при этом не теряя ни одной крупинки, их складывать, их сохранять и систематизировать, только тогда может быть в результате какое-то обобщение. Поэтому эта работа требует вот такого умения выполнять работу по поиску и сбору фактологии. Поэтому, первое - это ориентация на умение собирать, выявлять, тщательно сохранять материал.

Второе, это, конечно, ответственность за свое слово, потому что история психологии - это оценочная наука. В истории психологии происходит не только сбор материала и его обобщение, но и его оценка, оценка с позиций современного знания, оценка направлений, которые развивались, оценка школ, оценка ученых и т. д. При чем оценка тех людей, которые, часто, уже не могут возразить, которые не могут себя защитить, и эти оценки, как мы знаем, могут очень серьезно влиять и на восприятие людей, и на отношения, которые складываются к этим направлениям либо к этим историческим персоналиям. И поэтому надо понимать, какую ответственность берет на себя историк, когда он оценивает. Мы прошли ту страшную стадию в истории развития нашей науки, когда оценки носили идеологический характер. Мы узнали, как оценки порой калечили судьбы людей и на долгие годы предопределяли трагические судьбы [целых] направлений в развитии науки. Но, даже в том случае, если речь идет не о такой идеологической оценке, типа «направление враждебное, буржуазное, антинаучное», а такие оценки, к сожалению, часто присутствовали в нашей науке в 30-ые годы [ХХ столетия] и это была действительно суровая реальность, с которой приходилось иметь дело психологам. Но даже если оценки [были] более мягкие, например «реакционер науки» или «рефлексолог», [эта оценка] как ярлык «приклеивалась» к некоторым ученым и тиражировалась из одного издания в другое, при умалении всех других заслуг, даже такие оценки, они тоже влияют, они тоже определяют отношение, и это уже становится неким 
Научные труды Московского гуманитарного университета 2019 № 1

кодом, который закрепляется за ученым. Поэтому любая оценка не должна быть уничижительной. Надо всегда заниматься своеобразной исторической рефлексией, вернее саморефлексией, надо все время себя проверять и перепроверять [задавая вопросы]: «А правильно ли я оцениваю? А могу ли я так говорить об этом человеке? А для своего времени, не является ли то, что кажется нам ошибочным сегодня, нормальным и оправданным?». Эта ответственность за оценку, за анализ, за сформированное не только у себя, но и у тех, кто будет читать твою работу отношение - это очень важно.

Еще один очень важный момент, это, может быть способность к своеобразной исторической эмпатии, то есть способность как бы эмпатического включения в тот период, который изучается. Тут хочу привести слова Лосева, который говорил о том, что для того, чтобы понять, как мыслили люди прошлого, надо как бы мысленно перенестись туда, в это прошлое; надо попытаться посмотреть на мир глазами, людей, которые жили, попытаться пережить этот мир так, как переживали они и только тогда мы поймем, почему они так мыслили. Вот такая историческая эмпатия - это тоже, наверное, способность, которая отличает историка психологии. Мы же часто смотрим на прошлое только с позиций современности.

- Вера Александровна, вы говорили о том, что историк, с одной стороны, должен вжиться в деятельность, в творчество изучаемой персоналии, но одновременно должен стремиться сохранить объективность. Как это возможно? Как вы решаете эту проблему?

- Каждый историк, каждый историк психологии, конечно, подходит к этим проблемам со своими установками, со своим опытом, со своими знаниями, со своими научными приоритетами и отказаться от этого очень трудно. Единственный способ, как я считаю, это всегда себя проверять, задавать себе вопросы, то есть перепроверять свои мысли. В гуманитарной науке есть [важный] критерий достоверности знаний - это соотнесение своих выводов, выводов, которые ты получаешь [в ходе исследования], с выводами твоих коллег. Это очень важно. И если эти выводы принципиально сходятся, то получаешь некую уверенность, что твоя логика рассуждений правильная, и совпадает с большинством [мнений] авторитетных для тебя ученых. Если же, они принципиально расходятся, то это та самая проблемная ситуация, когнитивный конфликт, который ты должен для себя решить. Значит надо еще раз углубиться [в изучаемыq материал]. При этом общение с историческим текстом должно быть паритетное и ни в коем случае не должна быть позиция «над» при изучении психологической мысли прошлого, позиция как бы доминирования своей точки зрения. Не оценивать, а быстрее как бы пытаться понять, не учить предшественников, а может быть учиться у них. А там, в истории мысли прошлого, сокрыты такие интересные идеи, 
которые современная наука, может быть, не только утратила, но даже еще и осознала.

Например, кажется, что сейчас, в современной психологии человек трактуется исключительно как личность социальная, прежде всего. Вот эта социальная составляющая человека не меняется в его оценке. Мы социальные субъекты, мы преобразователи, мы должны переформатировать социальную среду и [вместе с этим преобразованием] мы изменяемся сами - это все правильные положения, такая субъектная позиция связывает социальный материал с активной преобразовательной деятельностью. Между тем, мы очень редко вспоминаем, что [человек] живет в природном ареале, он формируется в этом ареале, он несет на себе следы того природного окружения, в котором он существует. Он зависим от этого природного окружения. Мыслители прошлого, которые, вероятно, были ближе [чем мы] к природе это понимали. И я считаю, что это именно то философское направление в отечественной психологии, которое изначально ценно, потому что оно как раз обращает нас к этой природной ипостаси человека; оно показывает, что человек, живет в этом мире, он связан с ним. Другое дело, что, может быть, они умели чувствовать эту природу, они понимали ценность космоса, они воспевали, обожествляли космос. И космос для них был неким живым одухотворенным целым, с которым они активно общались, в котором они черпали потенциальную силу для своего развития. Мы эту способность утратили. Мы ориентируемся на социальное бытие, на свое взаимодействие с миром социальным, а вот природу мы используем очень прагматически, мы не умеем общаться с ней, мы умеем только использовать ее для своих целей. И вот сейчас, перманентно возникающие экологические катастрофы и кризисы, уже подсказывают [нам], что это серьезная ошибка.

У нас же была великолепная концепция Вернадского о ноосфере, где человек определяется как живое существо, не социальное, но живое! «Живое вещество» - так он называет свою работу, посвященную человеку, и показывает, что человек органично включен в биосферу и не может существовать без нее, он часть этой биосферы ${ }^{1}$. Хотя он, конечно, [такая] часть, которая может преобразовать биосферу силой своего разума. Поэтому, может быть нам надо учиться у наших предшественников этому умению чувствовать окружающий мир, быть в гармонии с этим окружающим миром и не нарушать эту гармонию посредством своих каких-то действий, а именно жить в гармонии со всем окружающим миром, а не только с социальным. В период становления научной психологии, критики духовных подходов отказались от понятия души, поскольку понятие действительно было не-

\footnotetext{
${ }^{1}$ Речь идет о книге: Вернадский, 1978.
} 
Научные труды Московского гуманитарного университета 2019 № 1

доступным для эмпирического исследования и было найдено более адекватные для этих целей понятия сознание, и психика и т. д. Но при этом мы утратили реальную целостность психического, мы раздробили его, мы атомизировали человека и его внутренний мир.

- Вера Александровна, а возможны ли сейчас открытия в истории психологии?

— Конечно. Могут быть открытия документальные, то есть может быть открыт какой-то новый источник, в котором содержатся интереснейшие уникальные знания, которых мы и не предполагали. Мы постоянно открываем для себя новые персоналии, поскольку, на самом деле, история психологии прошла только по «верхушкам», я имею в виду знаковые фигуры, фигуры важные, которые были в истории психологии. Однако, как говорил Вернадский, наука делается не только выдающимися учеными, и [даже] не столько, сколько вот [этими] тружениками науки, мастерами, которые выполняли порой рутинную и незаметную работу по подготовке философской или эмпирической почвы для проведения исследований. Этот пласт [науки] у нас совершенно не изучен. Работы многих тысяч «чернорабочих» от науки должны быть изучены, а их имена должны остаться в науке.

Наконец, опять же ссылаюсь на Вернадского, он был выдающимся ученым и историком науки и его идеи очень важны для истории психологии, он говорил о том, что даже те открытия, которые кажутся нам известными, но которые недооценивались на каком-то этапе, на новом витке науки приобретают какой-то совершенно новый смысл. И мы воспринимаем их уже как открытия, хотя они существовали, они были нами не оценены в силу наших установок, может быть, недостаточности знаний и т. д., но на новом витке они вдруг станут источником нового знания. Ну так, как это было с проблемой духовности, которая в течении XX века у нас, в нашей советской психологии практически была на периферии, отсутствовала [в тематике исследований], а сейчас вот к ней появился законный интерес. И это та перспектива, которая даст новые ростки психологического знания.

- Вера Александровна, известно, что наука развивается под воздействием многих факторов. Принято говорить о трех факторах: социокультурный, внутринаучный и личностный. Есть историки психологии, которые абсолютизируют какой-то один фактор и концентрируются на нем. Понятно, что надо учитывать все три фактора, но вот если говорить о Вас как об историке, понимая комплексность детерминации психологического знания, тем не менее, какой из этих факторов вас привлекает больше все-таки?

- Как человек, который вырос в русле системного подхода Б. Ф. Ломова, я просто не могу рассматривать изолировано один из факторов, как единственный, главный. Мне кажется, что наука такая сложная система, которая, 
конечно, детерминирована собственной логикой, поскольку есть некие закономерности развития науки, которые с неизбежностью на том или ином этапе выдвигают перед учеными проблему независимо от социального контекста. Наука имеет свою некую внутреннюю динамику роста и когда она подходит на определенном этапе к постановке какой-то проблемы, эта проблема ставится. Другое дело, насколько она может быть успешно решена в том или ином социальном контексте, в тот или иной исторический период, но она ставится и это неизбежно, это диктуется логикой развития науки.

Что касается личностно-персоналистического фактора, то в самом общем виде, любая идея зарождается все-таки в «психологической среде» конкретного человека, ее носителя. И поэтому игнорировать индивидуальные характеристики человека, его жизненный опыт, его образование, его установки, ценности и т.д. просто невозможно, иначе трудно понять, почему возникла у него эта мысль, почему она так сформулирована, почему так акцентированы те или иные положения в его работах. И, наконец, социальная ситуация. История нашей советской психологии показывает, сколь важен этот фактор. Поэтому, мне кажется, что эти три главные составляющие, эти три доминанты важнейшие, их учет в совокупности и позволяет понять историю развития психологического познания. Что касается просто интереса, здесь вы говорите об интересе, то интерес у меня, конечно, есть к личностным факторам. Я влюбляюсь в человека, которого изучаю, мне кажется он очень интересным, мне хочется больше его узнать, узнать о каких-то личных обстоятельствах его жизни, о том, что привело его к этому открытию, поэтому мне всегда увлекательно их изучать.

- Вера Александровна, вы говорили про открытия в истории психологии и про обаяние личности того, кого ты изучаешь, под влияние которой неизбежно попадаешь. А кто сейчас из персоналий отечественной психологии или просто философско-психологической мысли вас интересует? Необязательно тот, кем вы сейчас занимаетесь, но кто вам интересен в перспективе? Где нам ждать от вас открытий?

- Я не берусь с уверенностью утверждать, что мои какие-то исследования приведут к открытиям, это слишком серьезное заявление, но меня интересуют сейчас, во-первых, это те направления духовно-религиозной психологии, вернее так - отечественной философской психологии, которые существовали и развивались очень бурно в конце XIX - начале XX века в России.

В частности, мне представляются интересными работы В. П. Эрна, очень глубокого философа, который оставил интереснейшие работы о специфике русской философско-психологической мысли. И, пожалуй, тот анализ, который он дал, является наиболее обоснованным. По крайней мере, я пока не нашла какого-то более основательного анализа, разве может только в 
Научные труды Московского гуманитарного университета

2019 № 1

работах Лосского, которые тоже посвящены были истории русской философской ментальности. Поэтому, мне чрезвычайно интересен этот ученый. Интересны работы С. Булгакова, который тоже много пишет и о русской духовности, и об особенностях русской интеллигентности, и о русской философско-психологической мысли. В этом ключе можно назвать работы Лопатина, который у нас известен, к сожалению, очень мало. Это то, пожалуй, чем на перспективу я планирую заняться.

- У вас есть опыт разработки и экспериментальных тем в психологии (проблема общения), и теоретических (история психологии). Что объединяет и различает эти две области психологических исследований?

- Во-первых, история психологии - это некая точка опоры для тех, кто разрабатывает психологическую теорию. Доказательством является то, что ни один из крупных [теоретиков], методологов нашей науки, не мог обойтись без обращения к истории психологии. Был ли то Рубинштейн, работа которого - Основы психологии - это классический историко-теоретический труд, поскольку, он полон исторических экскурсов, ссылки [на работы других исследователей] занимают в нем огромное место; это блестящие работы Ананьева, нашего классика психологии, это работы Теплова, львиная доля которых посвящена истории психологии, так как это человек лирического склада и создатель оригинального нового направления, между тем, одновременно, и историк психологии, и методолог истории психологии; это и работа Выготского «Исторический смысл методологического кризиса» - совершенно блестящий исторический труд. Я думаю, что как раз продуктивность их как методологов, теоретиков, в значительной мере, определяется их высокой исторической культурой мышления, глубокими познаниями в области истории. Потому что любая теория - это обобщение, по сути дела, обобщение и систематизация. А в основе обобщения лежит опора на огромный фактологический фундамент. И история психологии как раз вооружает нас вот этой совокупностью фактов, совокупностью знаний, которые получены в истории человеческой мысли. И поэтому, чем шире фактологическая база, тем, естественно, более основательным будет обобщение. А в настоящее время знание истории психологии имеет еще и особый смысл, потому что мы находимся в достаточно сложной ситуации, психология переживает сейчас трудные времена самоопределения в новых условиях, с иным социальным существованием. И в этих условиях опора на опыт, который уже имелся, создает потенциальную уверенность в том, что психология справится с этими задачами и, кроме того, опыт - он всегда поучителен, он позволяет найти адекватные решения в каких-то сложных ситуациях.

- Вера Александровна, я знаю, что несколько дней назад вы завершили 
очередную монографию ${ }^{1}$. Могли бы вы в нескольких словах сказать, чему она посвящена?

- Это продолжение работ, которые уже проводились в области разработки методологии истории психологии ${ }^{2}$. В этой работе, наряду с вопросом о предмете истории психологии, несколько не традиционно формулируемом и понимаемом расширительно (поскольку обосновывается включение в предмет истории психологии не только научной психологической мысли, но и того массива обыденного психологического знания, который формируется и в житейской практике человека, и в области искусства, мифологии, религии), мы рассматриваем такие вопросы, которые пока в нашей истории отечественной психологии не поднимались или не были достаточно глубоко отрефлексированы. Это вопросы историографии, то есть дается понимание задач историографии, ее предметного поля, делается попытка проанализировать основные направления зарубежной и отечественной историографии, то есть рассматривается динамика развития истории психологии в течение XX столетия в России, определяются современные тенденции развития историографии.

Кроме того, ставится вопрос об источниковедении, поскольку, вообще то, история психологии - это источниковедческая дисциплина, он черпает свои знания из исторических источников. Вот такой ретроспективный анализ и, более того, регрессивный анализ - это главная стратегия исследования. Как говорил Блок, в истории психологии мы идем как бы от настоящего к прошлому, от более известного нам события к менее известному - вот таким образом мы углубляемся все дальше и дальше. И это менее известное событие, это прошлое, оно представлено, и предстает перед нами в виде исторических источников, то есть материализованных творений человеческого ума, зафиксированных на тех или иных носителях. Наиболее значимый и богатый такой носитель - это, конечно, слово, это письменный текст, который дошел до нас и который становится предметом нашего изучения. Иного пути познания прошлого нет, только через изучение источников. Следовательно, история психология - это область источниковедческого знания. Поэтому, разработка проблем источниковедения в истории психологии, обоснования источниковой базы проводимых исследований, описание и классификация источников изучения истории психологии, наконец, попытка построить периодизацию источников изучения истории психологии по их хронологической представленности на разных этапах

\footnotetext{
${ }^{1}$ Речь идет о монографии: Кольцова, 2008.

${ }^{2}$ В данном случае имеется ввиду монография, подготовленная по материалам докторской диссертации: Кольцова, 2004.
} 
Научные труды Московского гуманитарного университета

2019 № 1

развития нашей отечественной культуры - все это предмет специального рассмотрения в монографии.

И, наконец, в этой книге рассматривается проблема методов в истории психологии. Предпринята попытка классифицировать методы, дать их характеристику. Конечно, это лишь первый шаг, потому что это скорее поисковая такая работа в этой области, которая будет требовать продолжения и, может быть, каких-то коллективных усилий для ее дальнейшего развития.

- Будем с нетерпением ждать эту книгу. Вера Александровна, если можно, еще несколько вопросов по типу блищ-ответ. Скажите, пожалуйста, какой исторический период в истории отечественной психологии вас привлекает больше?

- Нy, во-первых, период Просвещения - XVIII век. Это блестящий век в истории культуры русской и в истории психологии, это зарождение психологии, зарождение научных идей в области психологии, это целая плеяда блестящих мыслителей, которые высказывали интереснейшие мысли. Второй период - это, конечно, может быть героический период создания первых лабораторий, когда трудами наших русских ученых закладывались уже основы психологии как самостоятельной науки. И мне хотелось бы, конечно, окунуться в дискуссии 1920-ых годов. Это был гордый, интересный период, когда люди высказывали мысли свободно, когда шла действительно настоящая научная дискуссия, и когда люди еще не были скованы какими-то уже сложившимися подходами, которые сейчас являются какой-то меркой нашего мышления и за рамки которых нам очень трудно выйти. А вот тогда это был действительно такой открытый поиск ответов на насущные вопросы психологии.

- Кто из ученых повлиял на вас именно как на историка психологии?

- Это, безусловно, мои учителя, которых я чту, помню и всегда буду им очень благодарна. Это Б. Ф. Ломов, Е. А. Будилова, Е. В. Шолохова, М. Г. Ярошевский, А. Н. Ждан, К. А. Абульханова. Это те мои учителя, которые для меня являются просто образцами ученых. Но я хотела бы назвать среди этих имен еще одного человека, труды которого для меня были очень важными - это Б. Г. Ананьев. Хотя, я и не встречалась с ним, непосредственно не работала, но тоже могу назвать себя его ученицей.

- Вера Александровна, одна из первых, а возможно и первая серьезная историко-психологическая работа была посвящена Плеханову. Правильно я понимаю?

- Правильно.

- Она была издана, опубликована уже, ну как минимум, лет 20 назад. Не хотели бы вы сегодня, уже с позиции вашего исторического опыта профессионала, да просто жизненного, вернуться к этой персоналии и еще раз проанализировать творчество этого ученого? 
- Мне очень интересен Плеханов, однако не знаю, смогу ли я к нему вернуться, потому что у меня есть уже какие-то планы, а ведь любая персоналия, ее анализ требует очень серьезного углубления в эпоху и в личность, и в идеи и т. д. И поэтому надо выбрать время для того, чтобы этим заняться. Но мое глубокое убеждение, состоит в том, что Плеханов - пока еще, недооцененная персоналия в истории развития психологических идей, потому что это был необыкновенно эрудированный человек, который затронул массу проблем, которые сейчас являются актуальными для социальной психологии, он рассматривал их с достаточно однозначной и определенной позиции - с позиции экономического детерминизма. С моей точки зрения, он был очень глубоким марксистом, хотя понимал марксизм, может быть, не совсем так, как его трактовали впоследствии, но, может быть, как раз в этих его представлениях было сокрыто много интересного.

- Вера Александровна, если вы все-таки решитесь на подобную работу, это было бы одно из первых, своего рода, лонгитюдных исследований в истории психологии - по сути, вы возвращаетесь к анализу персоналии, которую уже знаете, хорошо изучили, но рассматриваете в новых обстоятельствах. И важно, что это будет делать не другой исследователь, таких работ много, а один и тот же ученый. Если вы все же решитесь на эту работу, то мы бы с удовольствием опубликовали эту работу.

- Спасибо, конечно, это было бы интересно...

- Вера Александровна! Если бы вы могли и хотели бы обратиться с очень кратким обращением, естественно в контексте истории психологии, к трем категориям психологов - студенты, молодые ученые, которые только начинают свой путь в науке и авторитетные ученые, чтобы вы им сказали? С каким бы обращением или призывом вы к каждой из этих категорий обратились? Что бы посоветовали?

- Трудный вопрос. Особенно трудно дифференцировать, скажем, студентов и молодых ученых. Что касается студентов, то я посоветовала бы не пропускать ни одного шанса для углубления своих знаний, потому что, на самом деле, кажется, что пять лет - это достаточно много, ну пропущу я какой-то курс или там месяц, два занятий, а потом уже нагоню. Однако, на самом деле, теряется драгоценнейшая информация, которую, возможно, не удастся никогда восполнить. Отсутствие на лекциях не позволяет понять, какие-то оригинальные мысли преподавателя, которые он не всегда имеет возможность изложить в своих публикациях, поскольку его живое, непосредственное общение с аудиторией, его мысли и размышления, система аргументов и доказательств, они часто бывают представлены только в устной форме, только здесь и сейчас, на лекциях. А потом вдруг человек осознает, что он много потерял, что вот он не прослушал какой-то курс, он 
Научные труды Московского гуманитарного университета

2019 № 1

невнимательно вник в какие-то проблемы, которые обсуждались, то есть, чтобы не было сожаления об утерянных возможностях, надо максимально использовать это замечательное время и возможность.

Это, пожалуй, самое счастливое время, когда еще не надо отдавать, но когда есть возможность много, много получать. Потому что потом начнется работа, и эта работа потребует уже именно отдачи, и меньше будет возможностей, чтобы пополнять свои знания. Поэтому надо учиться и использовать это время на сто процентов.

Ну, что касается молодых ученых, то я, конечно, понимаю, насколько им сейчас трудно. Почему трудно? Я вспоминаю себя в молодые годы, когда я могла сконцентрироваться на научной работе, могла сидеть неделями, не выходя из библиотеки, обложившись книгами, читая их. Сейчас, как правило, молодой специалист, начиная свой профессиональный путь должен, прежде всего, думать о том, как он будет себя обеспечивать материально. И он должен сочетать научную работу с чтением лекций, с работой где-то дополнительно, потому что, конечно, недостаточное финансирование еще не позволяет полностью сосредоточиться только на научной работе. Но тут, важно установить приоритеты, что должно быть главным, потому что иногда получается так, что человек начинает подрабатывать ради того, чтобы учиться, а потом, наоборот, уже учеба становится дополнительной, некой вторичной задачей, а уже основное внимание и силы переключает на себя эта подработка. Важно сохранить установку, ориентацию на то, что наука должна быть главным и основным в жизни. И тогда, я думаю, можно преодолеть любые трудности.

Ну, а что касается уже людей с опытом, «маститых» ученых, как вы говорите, здоровья им, счастья и долгой-долгой плодотворной работы, потому что их работы и труды нам очень нужны.

- Чего не хватает современному сообществу историков психологии в нашей стране?

- Я думаю, что современное сообщество историков психологии, а оно немногочисленно, хотя, конечно, оно никогда и не было многочисленным, поэтому и в настоящее время тоже не может быть таким, хотя бы потому, что, как я уже говорила, не каждый психолог может быть историком психологии. Кропотливость, сбор материала, вся эта рутинная работа, которая отнимает очень много сил, времени и дает результат или эффект не сразу и далеко не сразу, по сравнению с исследователем, какого-то экспериментального направления или работающего в области прикладной психологии. Поэтому сообщество историков психологии было небольшим во все времена, я бы сказала, что оно, наоборот, сейчас даже немного расширилось, потому что сняты идеологические барьеры, пришли люди с разными интересами, 
и они могут реализовать эти свои интересы в области истории психологии. Ну а возможности, я думаю, они даже больше, чем были прежде, нет запретов, а для истории психологии это очень важно. Другими словами, нет идеологически запрещенных тем, нет идеологически запрещенных персоналий и, при серьезном обосновании, мы можем заняться той проблемой или той персоналией, которая нас интересует. Поэтому, я считаю, что сейчас историкам психологии работать и интереснее, и у них есть больше возможностей для продуктивной работы. Не хватает только, может быть какой-то мотивации или знаний, но это дело, зависимое только от самого исследователя.

- Я слышал мнение, что когда ты проводишь какое-то эмпирическое исследование, от замысла и формулировки гипотезы до получения результатов, ты самореализуешься в полной мере. А работа историка психологии это все-таки возвеличивание той персоналии, которой занимаешься, или той эпохи, которую изучаешь. Могли бы вы возразить этой точке зрения? В какой мере история психологии дает возможность самореализоваться исследователю?

- Я думаю, что история психологии дает исследователю, может быть, столь много, сколько не дает какая-то другая область знаний. Потому что, во-первых, это огромное удовольствие, это, пожалуй, самая интересная страница творчества ученого, когда ты находишь какой-то интереснейший факт, новый документ, то возникает необъяснимое чувство какого-то подъема, если не сказать, что какого-то восторга даже. Ты прикасаешься к чему-то личному, и как раз, если амбиции не мешают тебе работать в этой области, то самореализация состоит именно в том, чтобы достойно отразить то, что является предметом твоего изучения. И в этом проявляется твоя самореализация, ты осознаешь какую-то свою важную функцию, ты принимаешь на себя выполнение этой функции, с ответственностью к ней относишься и получаешь удовольствие от осознания того, что ты ее выполнил. Ты сохраняешь, вносишь в современный научный оборот то, что было сделано в прошлом. Мне кажется, что это насколько великая миссия, великая цель, что ее реализация и достижение, обеспечивают полную самореализацию человека.

- Представим ситуацию, что у вас есть возможность как у историка психологии побеседовать с любым персонажем истории нашего государства или мировой истории. С кем бы вы хотели встретиться, побеседовать, задать вопросы?

- В истории психологии?

- Нет, вообще в истории.

- Мне было бы очень интересно побеседовать с Дашковой - это потрясающая женщина, которая создала первый российский университет, ой, 
простите, первую российскую Академию наук. Именно российскую академию наук, поскольку созданная Петром Первым в Санкт-Петербурге Академия, называлась Санкт-Петербургская академия наук. А вот Российскую Академию наук создала Дашкова, была ее президентом. B XVIII веке женщине быть президентом академии наук - это, конечно, трудно вообразимо. Мне кажется, что это чрезвычайно интересная женщина, и мне было бы интересно с ней побеседовать.

Я бы с удовольствием побеседовала бы с М. К Валицкой, она была первой русской женщиной-экспериментатором. Интересно, что привело ее в экспериментальную психологию тогда, когда об этом говорили и знали лишь какие-то единичные просвещенные люди.

Было бы, конечно, очень интересно поговорить с В. М. Бехтеревым, который для меня является своеобразной «глыбой», таким совершенно потрясающим ученым, который поражает широтой своих интересов, какой-то фундаментальностью своих мыслей и идей, при чем в разных направлениях науки, включая и психологию. Бехтерев одновременно совмещал в себе и дар талантливого ученого-экспериментатора, и необыкновенной широты теоретика, и поэта блестящего, и человека общественных, очень широких интересов. То есть для меня это личность совершенно уникальная, и он для меня очень интересен.

А еще, мне очень интересен А. А. Токарский - человек, который был одним из создателей экспериментальных лабораторий, но который поражает меня своей патриотической установкой, патриотической имеется в виду по отношению к своей науке. Этот ученый, который прекрасно говорил на многих европейских языках, но принципиально в общении с коллегами использовал только русский язык, заявляя о том, что он мечтает, чтобы русский язык стал языком межнационального научного общения. Мне кажется, что нам не хватает как раз такой патриотической позиции по отношению к своей науке, к своим достижениям. Кроме того и его жизненный путь, и его трагическая ранняя смерть, и его усилия по созданию нашей науки очень привлекают к этой личности.

Ну и, конечно, трудно перечислить всех других, с кем бы мне хотелось пообщаться.

- Спасибо вам, Вера Александровна, большое за беседу. Удачи и новых творческих успехов на ниве познания истории отечественной психологии!

\section{СПИСОК ЛИТЕРАТУРЫ}

Вернадский, В. И. (1978) Живое вещество. М. : Наука. 358 с. 
История и некоторые вопросы современного состояния экспериментальных исследований в отечественной психологии (1989): сб. научн. трудов. М. : ИПАН СССР.

История становления и развития экспериментально-психологических исследований в России (1990). М. : Наука.

Кольцова, В. А, Олейник, Ю. Н. (1986) 100-летие развития экспериментальной психологии в России // Психологический журнал. Т. 7. № 3. C. $157-165$.

Кольцова, В. А. (1981) Проблемы социальной психологии в трудах Г. В. Плеханова (К 125-летию со дня рождения) // Психологический журнал. Т. 2. № 5. С. 137-149.

Кольцова, В. А. (2004) Теоретико-методологические основы истории психололгии. М. : Изд-во «Институт психологии РАН». 416 с.

Кольцова, В. А. (2008) История психологии: Проблемы методологии. М. : Изд-во «Институт психологии РАН». 511 с.

Дата поступления: 12.02.2019 2.

Олейник Юрий Николаевич - кандидат психологических наук, доцент, заведующий кафедрой общей психологии и истории психологии Московского гуманитарного университета. Адрес: 111395, Россия, г. Москва, ул. Юности, д. 5. Эл. адрес: yurii03@mail.ru

Кольцова Вера Александровна- доктор психологических наук, профессор, заведующая лабораторией истории психологии и исторической психологии Института психологии РАН.

Oleinik Yuri Nikolaevich, Candidate of Psychological Sciences, Associate Professor, Head of the Department of General Psychology and History of Psychology, Moscow University for the Humanities. Postal address: 5 Yunosti, 111395, Moscow, Russia. E-mail: yurii03@mail.ru

Koltsova Vera Aleksandrovna, Doctor of Psychology, Professor, Head of the Laboratory of the History of Psychology and Historical Psychology, Institute of Psychology of RAS.

\section{Для цитирования:}

Олейник Ю. Н., Кольцова В. А. История психологии как направление психологической науки и пространство творческой самореализации индивидуальности ученого [Электронный ресурс] // Научные труды Московского гуманитарного университета. 2019. №1. URL: http://journals.mosgu.ru/trudy/article/view/941 (дата обращения: дд.мм.гг.). DOI: 10.17805/trudy.2019.1.1 